Proceedings

\title{
Comparative Study of Flowering Phenology of Selected Plant Life Forms Located in Urban and Rural Environments in Central Europe. Preliminary Results ${ }^{\dagger}$
}

\author{
Krisztina Verbényiné Neumann* and Szilárd Czóbel
}

Citation: Neumann, K.V.; Czóbel, S. Comparative Study of Flowering Phenology of Selected Plant Life Forms Located in Urban and Rural Environments in Central Europe. Preliminary Results. Proceedings 2021, 68, x.

https://doi.org/10.3390/xxxxx

Academic Editor:

Published: date

Publisher's Note: MDPI stays neutral with regard to jurisdictional claims in published maps and institutional affiliations.

Copyright: (c) 2021 by the authors. Submitted for possible open access publication under the terms and conditions of the Creative Commons Attribution (CC BY) license (http://creativecommons.org/licenses/by/4.0/).
Department of Nature Conservation and Landscape Management, Hungarian University of Agriculture and Life Sciences, Páter Károly u. 1, Gödöllő 2100, Hungary; neumann.krisztina86@gmail.com

* Correspondence: neumann.krisztina86@gmail.com

+ Presented at the 1st International Electronic Conference on Biological Diversity, Ecology and Evolution, 1531 March 2021; Available online: https://bdee2021.sciforum.net/.

\begin{abstract}
Global climate change has unforeseeable ramifications for the ecosystem of our planet Earth. In Europe, more than half of the vascular plant flora may become endangered by the year 2080 as a result of climatic changes. According to the Coperniscus Program's sutdy of European municipalities Budapest is one of the most affected cities by global warming. Urban climate conditions are considered similar to the changing global climate conditions. To find out how excess heat in urban environments affects the phenological flowering patterns of species we planted specimens representing 6 different life-forms of the Raunkiær system (phanerophytes, chamaephytes, hemicryptophytes, geophytes, hemitherophytes, therophytes). The species of the ex situ experiment were planted in two different mesoclimatic locations, in the ELTE Botanical Garden, Budapest and in the Hungarian University of Agriculture and Life Sciences Gödöllő Botanical Garden. Each lifeform was represented by at least 5 species and each species by $5-5$ specimens in both locations. By recording phenological data we followed Primack's method. All the species in the experiment showed an average 7.62 days earlier flowering onset in Budapest, Füvészkert. The maximum of the flowering showed 12.94 days of difference, while the end of flowering showed 2.9 days of difference, with the earlier being Budapest, Füvészkert. There is a strong significant difference $(p<0.001)$ in the onset of the flowering of Globularia cordifolia between the locations, regarding the peaks of flowering there is a strong significance $(p<0.001)$ for Inula ensifolia, regarding the end of flowering there is a strong significance $(p<0.001)$ for Polygonatum multiflorum. The average duration of the flowering of all species was 4.72 days longer in Budapest compared to Gödöllő. To clarify other driving forces and the role of abiotic parameters in the flowering phenology patterns, further study is required.
\end{abstract}

Keywords: flowering phenology; climate change; urban heat island

\section{Introduction}

Climate change has unforeseeable ramifications for the ecosystem of our planet Earth. In Europe, more than half of the vascular plant flora may become endangered by the year 2080 as a result of climatic changes (Thuiller et al., 2005). Based on current research it seems that climate change can no longer be stopped. Therefore, it is crucial to investigate possible adaptations (Li et al., 2019).

Urban climate conditions are considered similar to the changing global climate conditions; therefore, many researchers study urbanized areas as small-scale experiments, or models, of global climate change (Ziska et al., 2003). Thus, it is key to examine the patterns and shifts in the patterns of flowering phenology in urban areas compared with rural ones. Cities are strongly affected by climate change. 
Fifty years of data from the Copernicus Program on more than 100000 European municipalities confirm that the continent is heating up at every latitude. In a third of these municipalities, the average temperature has risen by more than $2{ }^{\circ} \mathrm{C}$ between the $1960 \mathrm{~s}$ and the last decade (http3, http4). The survey compared the mean temperatures of the municipalities of the period between 1961-1970 with the period between 2009-2018. According to the report of this program mean temperature of Budapest increased from $8.04{ }^{\circ} \mathrm{C}$ to $12.04{ }^{\circ} \mathrm{C}$, and in Gödöllo" from $7.56^{\circ} \mathrm{C}$ to $10.76^{\circ} \mathrm{C}$.

Phenology is the study of the timing of recurrent biological events, the causes of their timing with regards to biotic and abiotic forces, and the interrelation among phases of the same or different species (Lieth 1974). Many research shows that temperature change significantly affects the life cycle of plants (e.g. Scheifinger et al., 2003, Kunkel et al., 2004, Hansen et al., 2006, Lehoczky et al., 2016).

Towards the end of the last century, phenological observations were recognized for their capability to visually and quantitatively assess climate change effects on ecosystems. Several studies demonstrate significant shifts in phenological phases of plants across Europe (e.g., Menzel and Fabian 1999; Menzel 2000, Chmielewski and Roetzer 2001, Schleip et al., 2009). Shifts in phenological events in the Carpathian Basin are particularly poorly documented, with a few exceptions coming from the works of Keresztes (1984), Walkovszky (1998), Schieber et al. (2009), Eppich et al. (2009), Molnár et al. (2012), Varga et al. (2012), Lehoczky et al. (2016), and Szabó et al. (2016). Keresztes (1984), Walkovszky (1998), and Varga et al. (2012) are focusing on their study on Robinia pseudoacacia, a non-native species for the Carpathian Basin, however, there is a lack of studies with emphasis on native species' phenology in Hungary. There is less available phenological data on wildgrowing plants, then from cultivated species (Walkovszky 1998, Hunkár 2012). Szabó et al. (2016) showed in their study based on the long-term data from the Hungarian Meteorological Service recorded between 1952 and 2000, that native plant species advanced their flowering time (1952-2000) by 1.9-4.4 days per decade.

A comprehensive understanding of species phenological responses to global warming requires observations that are both long-term and spatially extensive. Long-term data series deriving from the same place are rare (Hunkár et al., 2012). It is also very important to choose the correct methodology for the research. Primack (1985) described the methodology of collecting flowering phenology data. For the observation of individual plants, he suggests counting every flower open on the entire plant on every day that the plant is in bloom, to note the date of first flowering, the date of the last flowering, and the date on which the most flowers are open (date of maximum flowering).

Several previous studies (e.g., Menzel 2000, Roetzer et al., 2000, Walkovszky 1998, Eppich 2009) confirmed that flowering phases advanced during the 20th century, which is connected with the increasing temperature. Szabó et al. (2016) examined flowering phenological records for six species (Convallaria majalis, Taraxacum officinale, Syringa vulgaris, Sambucus nigra, Robinia pseudoacacia, Tilia cordata) based on phenological observations from the Hungarian Meteorological Service recorded between 1952 and 2000. Altogether, four from the six examined plant species showed a significant advancement in flowering onset with an average rate of 1.9-4.4 days per decade. Using a long-term data series of 144 years (18511994) Walkovszky (1998) showed 3-8-day advancement in the flowering date of Robinia pseudoacacia, relating the event to the mean temperature of March-May.

This study aims to find out how excess heat in urban environments affect the phenological flowering patterns of species belonging to different life forms, and how different the effect is in colder rural mesoclimactic environments.

To observe this, we planted plants representing six different life forms in two distinct locations. One was in downtown Budapest in ELTE Botanical Garden (Füvészkert), and the other in MATE Botanical Garden of Gödöllő. The flowering of the plants was recorded between the 1 March and 25 December in 2020. 
We hypothesized locations with higher mean temperatures would result (i) in an earlier onset and (ii) and an earlier end of flowering, compared to colder locations.

\section{Materials and Methods}

\subsection{Study Area}

Examination covering the entire vegetation cycle of species have been implemented in the Experimental Site of Hungarian University of Agriculture and Life Sciences Gödöllő Botanical Garden (47 35'36.2" N 19²2'06.2" E, 250 m elevation, mean annual temperature is $9.7^{\circ} \mathrm{C}$; the average amount of precipitation is $560 \mathrm{~mm}$ ) (Dövényi et al., 2008, Szirmai et al., 2014) and the ELTE Botanical Garden (Budapest 47²9'05.6" N 1905'05.7" E, $114 \mathrm{~m}$ elevation, mean annual temperature is $10.4{ }^{\circ} \mathrm{C}$; the average amount of precipitation is 514 mm) (Dövényi et al., 2008, Orlóci et al., 2019).

For the 34 species, 34 homogenous row shaped patches have been created within the two selected areas with 5 repetitions by species and by location.

\subsection{Ex Situ Phenological Experiment}

We planted specimens representing 6 different life-forms of the Raunkiær system (phanerophytes, chamaephytes, hemicryptophytes, geophytes, hemitherophytes, therophytes). Each category was represented by at least 5 species (Table 1) and each species by 5-5 specimens in both locations (two botanical gardens one in Budapest the other in Gödöllő).

The observation units were put in standard-sized flowerpots with a diameter of 27 $\mathrm{cm}$ for phanerophytes, and $14 \mathrm{~cm}$ for the rest, containing at least one specimen from the given species. We tried to maximize genetic conformity in each species. This was achieved by using clones in phanerophytes, obtained from the Hungarian University of Agriculture and Life Sciences Soroksári Botanical Garden. In the case of seed-sown species, the propagating material was collected from one specimen per species in the Gödöllő Botanical Garden and the Füvészkert, while in the case of other species we obtained specimens propagated from the horticulture of Beretvás \& Co. Ltd. We collected and planted the specimens to the experimental patches during December of 2019.

\begin{tabular}{|c|c|c|}
\hline $\mathrm{Ph}$ & $\mathrm{Ch}$ & $\mathrm{He}$ \\
\hline Cormus sanguinea & Dianthus plumarius & Euphorbia polychroma \\
\hline Prumus spinosa & Sedum album & Ajuga reptans \\
\hline Ligustrum vulgare & Vinca minor & Inula ensifolia \\
\hline Prumus fruticosa & Thymus vulgaris & Sedum acre \\
\hline Cotimus coggvgria & Cerastium tomentosum & Briza media \\
\hline Prumis tenella & Globularia cordiflora & \\
\hline \multicolumn{3}{|l|}{ Rosa spinosissima } \\
\hline $\mathbf{G e}$ & HT & Th \\
\hline Iris pumila & Daucus carota $^{* 8}$ & Hibiscus trionum \\
\hline Polygonatum multiflorum & Dipsacus pilosus $^{* *}$ & Solanum nigrum \\
\hline Convallaria majalis & Dipsacus lacinatus ${ }^{* *}$ & Silene latifolia \\
\hline Galanthus nivalis $^{*}$ & Capsella bursa-pastoris & Portulaca oleracea \\
\hline \multirow[t]{2}{*}{ Eranthis hyemalis ${ }^{*}$} & Malva sylvestris ${ }^{* *}$ & Consolida regalis \\
\hline & & Papaver rhoeas \\
\hline
\end{tabular}

Table 1. The species included in the experiment grouped by life-forms. ${ }^{*}$ the species were introduced after the start of the growing season, therefore were not included in the record; ${ }^{* *}$ 
resulting from their life-form, flowering in the first year is not expected (Krumbiegel, 2008).

To minimize external factors, we used a standard soil mix and we put the plants in the patches of similar characteristics and followed the same protocol during their observation. In practice, this meant frequent weeding and regular irrigation during the summer months. Observations were realized weekly on the same day of the week from March to December of 2020, on both locations, collecting flowering phenological data. For the study of the flowering phenological data, we used Primack's (1985) method. The timing of the start, peak, and end of flowering was recorded in an Excel sheet. We recorded the end of flowering when there was no more flower on any of the specimens. The peak was the first day from all the dates when the specimen had the maximum number of flowers noticed. In case of solitary flower we recorded the number of flowers, while in case of Briza media, Capsella bursa-pastoris, Sedum album, and Thymus vulgaris we recorded the number of inflorescences for each observation unit. During the growing season specimens of Cornus sanguiena, Ligustrum vulgare, Prunus tenella, Rosa spinosissima, Dianthus plumarius, Sedum album, Vinca minor, Thymus vulgaris, Cerastium tomentosum, Ajuga reptans, Inula ensifolia, Sedum acre, Briza media, Iris pumila, Polygonatum multiflorum, Capsella bursa-pastoris, Hibiscus trionum, Solanum nigrum, Silene latifolia, Portulaca oleracea, Consolida regalis, Papaver rhoeas flowered. In case of Portulaca oleracea we could only infer the flowering from the fruiting because there was no flower detected at the times of observation. The flowering of the Papaver rhoeas could only be detected on one of the locations, on the other a short flowering period could be inferred from the buds and fruits. Therefore, these two species were excluded from the evaluation of the flowering data. On both observation locations only Prunus tenella, Dianthus plumarius, Sedum album, Vinca minor, Thymus vulgaris, Cerastium tomentosum, Ajuga reptans, Inula ensifolia, Sedum acre, Briza media, Iris pumila, Polygonatum multiflorum, Capsella bursa-pastoris, Hibiscus trionum, Solanum nigrum, Silene latifolia flowered. All species-except Iris pumila-produced enough flowers for statistical analysis of the data.

\subsection{Statistical Analysis}

Figures were created with Sigma Plot 12.0. For statistical analysis, we used Windows Excel 2016, while we calculated the two-tailed t-test to show the difference between locations. The results shown in the figures are the averages and standard deviations for each species in both locations.

\section{Results}

From the 16 species flowering on both locations 12 species Globularia cordiflolia (Figure 1), Briza media (Figure 2), Hibiscus trionum (Figure 3), Silene latifolia subsp. alba, Inula ensifolia, Polygonatum multiflorum, Dianthus plumarius, Sedum album, Vinca minor, Thymus vulgaris, Cerastium tomentosum, and Capsella bursa-pastoris confirmed our hypothesis, by flowering earlier in ELTE Botanical Garden than in Gödöllö. From the listed species the average difference in the onset of flowering was 10.66 days. The Solanum nigrum, Sedum acre started the flowering on the same week on both locations. The Prunus tenella, Ajuga reptans, and the Iris pumila started to flower earlier in Gödöllö, contradicting our hypothesis. Species with the earlier onset of flowering happening in Gödöllő had an average difference of 2.2 days. All the species in the experiment averaged at 7.62 days earlier flowering onset in Budapest, Füvészkert. The peak of the flowering had 12.94 days of difference, while the end of flowering had 2.9 days of difference, with the earlier being Budapest, Füvészkert.

The Globularia cordifolia, Inula ensifolia, Polygonatum multiflorum, Dianthus plumarius, Thymus vulgaris, Cerastium tomentosum and Capsella bursa-pastoris had an earlier onset as well as an earlier end of flowering in Budapest, Füvészkert compared to 
Gödöllőn. The flowering of Sedum album had an earlier onset in Budapest and a simultaneous end on both locations. The flowering of Hibiscus trionum and Vinca minor started earlier and ended later in Budapest. The flowering of Ajuga reptans and Iris pumila started later and ended later in Budapest. The flowering of Prunus tenella started later in Budapest and ended at the same time. The flowering of Solanum nigrum and Sedum album started in the same week and ended earlier in Budapest. The flowering of Silene latifolia subsp. alba started in the same week in both locations, but in contrast to the former two ended later in Budapest. The average duration of the flowering of all species was 4.72 days longer in Budapest compared to Gödöllő. Flowering duration of Hibiscus trionum, Silene latifolia subsp. alba, Globularia cordifolia, Briza media, Sedum album, Vinca minor, Capsella bursa-pastoris, Ajuga reptans, and Iris pumila was longer in Budapest, compared to Gödöllő.

According to the statistical analysis, there is a strong significant difference $(p<0.001)$ in the onset of the flowering of Globularia cordifolia between the locations. Polygonatum multiflorum, Cerastium tomentosum, and Capsella bursa-pastoris showed a medium significance $(p<0.01)$. There was a still significant but weaker connection $(p<0.05)$ for the onset of flowering of Thymus vulgaris between the two locations.

Regarding the peaks of flowering there was a strong significance $(p<0.001)$ for Inula ensifolia medium significance $(p<0.01)$ for Globularia cordifolia, Dianthus plumarius Thymus vulgaris Cerastium tomentosum Capsella bursa-pastoris, and a weaker significance ( $p$ $<0.05$ ) for Polygonatum multiflorum.

Regarding the end of flowering there is a strong significance $(p<0.001)$ for Polygonatum multiflorum, medium siginificance $(p<0.01)$ for Globularia cordifolia, Thymus vulgaris, and a weaker significance $(p<0.05)$ for Sedum acre, Dianthus plumarius, and Cerastium tomentosum.

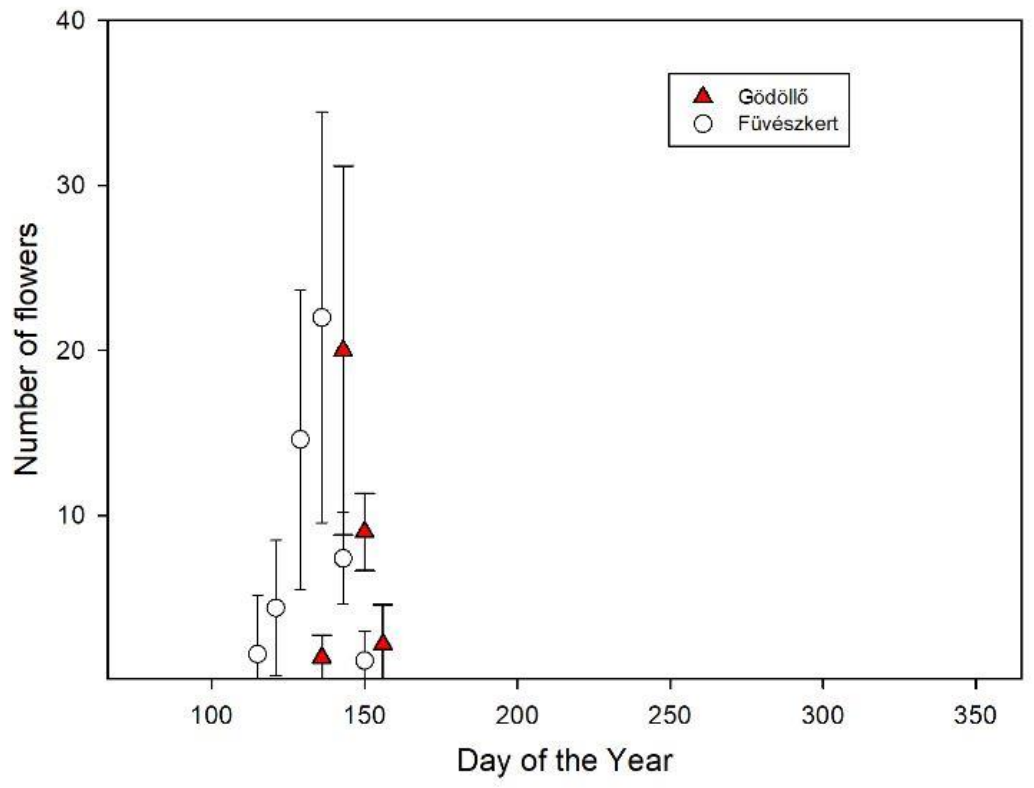

Figure 1. The flowering period and pattern of Globularia cordifolia. 


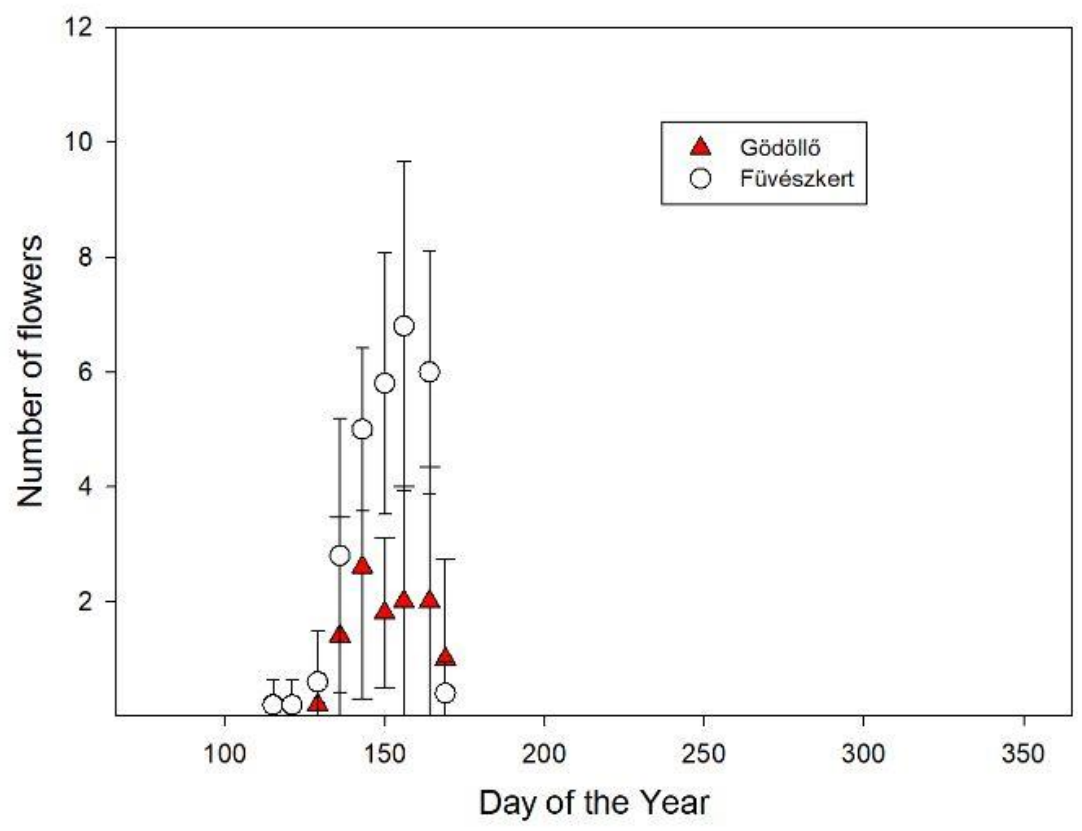

Figure 2. The flowering period and pattern of Briza media.

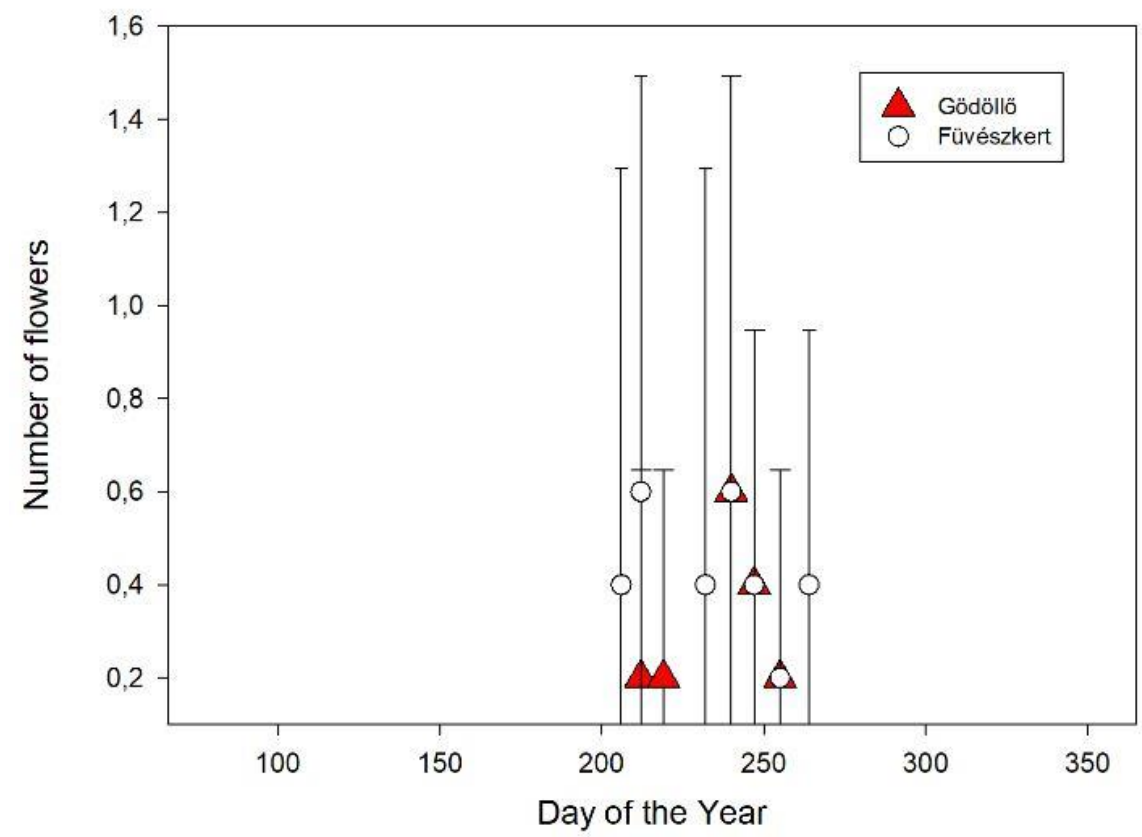

Figure 3. The flowering period and pattern of Hibiscus trionum.

\section{Discussion}

Our results show that the onset and end of flowering occurred earlier in the capital city with a higher mean temperature than in the lower mean temperature rural area. However, the flowering period lasted longer in Budapest than the rural area with a $3{ }^{\circ} \mathrm{C}$ lower mean temperature. Only a few studies (e.g., Roetzer et al., 2000, Ziska et al., 2003, Neil \& Wu 2006, Jochner et al., 2012) focused on the difference in phenological patterns between urban and rural areas. Roetzer et al. (2000) analyzed data for four spring-blooming plants from 10 central European observation stations between 1951 and 1995. At almost all stations, the plants tended to bloom earlier in urban areas than in surrounding rural areas by 
about 2-4 days. Jochner et al. (2012) investigated the role of elevation and urbanization in the shift of flowering phases of tree species, and an advance of 2.6-7.6 days was observed between an entirely rural area and an entirely urban one. Roetzer et al. (2000) showed, that in European cities with strong urban climate effects e.g., Munich, Vienna and Hamburg, phenophases are beginning 3-16 days earlier. His results are in agreement with our results as the plants grown in Budapest, Füvészkert have on average 7.62 days earlier onset of flowering compared to Gödöllö. This result could mean that downtown Budapest is strongly affected by the urban climate effect. Researchers attribute advanced flowering in urban environments to the Heat Island Effect (Neil \& Wu 2006), which is clearly noticeable in our results as well.

Extension of growing periods in urban habitats has also been reported in the northern hemisphere (e.g., Zhang et al., 2004, Neil and Wu 2006) while possible protracted flowering periods within urban landscapes are poorly studied, especially in Europe. Davis et al. (2016) examined eucalyptus trees in streets in Sidney, Australia, and observed, that 3 tree species from the family Myrtaceae showed a significantly longer flowering period on the streets of the city than in their natural habitats. Our results are consistent with this study, as the species participating in the experiment had a 4.72 days longer flowering period in Budapest compared to Gödöllö.

Compared to the onset of flowering there are significantly fewer studies regarding the end of flowering and the possible advancement of it. Masetti et al. (2015) studied Tilia $\mathrm{x}$ europea in Florence, Italy, and concluded that both the start and end of flowering advanced by 1.4 days in urban areas. In our experiment Globularia cordifolia, Inula ensifolia, Polygonatum multiflorum, Dianthus plumarius, Thymus vulgaris, Cerastium tomentosum, and Capsella bursa-pastoris started to flower earlier in Budapest, Füvészkert compared to Gödöllö. All the species in the experiment had an average of 2.9 days advancement at the end of flowering in Budapest, Füvészkert compared to Gödöllö, which is in agreement with the observation of Masetti et al. (2015).

Nail and $\mathrm{Wu}$ (2006) observed the phenomenon that early spring bloomers in these environments tend to be more sensitive than mid- or late-spring bloomers. For the future investigation of this conclusion, we will introduce 2 early spring bloomers Eranthis hyemalis and Galantus nivalis from 2021.

Is there a significant difference between the years? Exactly with which abiotic parameters do the flowering phenology correllate? These are questions to be addressed in future studies.

Based on our result, not all of these questions can be answered. Peñuelas and Filella (2001) showed that the advancements of phenological events were significantly correlated, with temperature increase over the 30 years before then, however, the significance of other factors is unclear. According to Rathcke and Lacey (1985) and Neil and Wu (2006) photoperiod, temperature, and soil moisture have been recognized as the main environmental triggers for leafing and flowering. Zhang et al. (2004) claim that it is the interaction between temperature and photoperiod that is responsible for initiating flowering Szabó et al. (2016) claim that the flowering phenophase shows the strongest correlation with the average air temperature of a few months preceding the event, while Eppich et al. (2009) came to the conclusion that the average of the daily temperature fluctuation in the given period and the number of frosty days are the most important triggers for flowering phenology. To clarify the driving forces of flowering phenology patterns we installed micrometeorological equipment to continuously measure abiotic parameters on both locations.

\section{Conclusions}

The experiment confirmed our hypotheses. As a result of increasing temperature, we can count on earlier onset and end of flowering. Excess heat in urban environments can serve as model of ongoing and upcoming global warming. 
Author Contributions: Krisztina Verbényiné Neumann performed the experiment, analysed the data and wrote the paper, Szilárd Czóbel designed and supervised the project. All authors have read and agreed to the published version of the manuscript.

\section{Institutional Review Board Statement:}

\section{Informed Consent Statement:}

\section{Data Availability Statement:}

Acknowledgments: This research was supported by the ÚNKP-20-3-I New National Excellence Program of the Ministry for Innovation and Technology of Hungary.

\section{References}

1. Chmielewski, F.-M.; Rötzer, T. Response of tree phenology to climate change across Europe. Agric. For. Meteorol. 2001, 108, 101112, doi:10.1016/s0168-1923(01)00233-7.

2. Davis, A.; Major, R.E.; Taylor, C.E. Do trees flower longer in the city? A comparison of flowering eucalyptus trees in streets, remnants and continuous forest and their association with nectarivorous birds. Urban. Ecosyst. 2016, 19, 735-747, doi:10.1007/s11252-015-0515-z.

3. Dövényi, Z.; Ambrózy, P.; Juhász, Á.; Marosi, S.; Mezősi, G.; Michalkó, G.; Tiner, T. Magyarország kistájainak katasztere Inventory of microregions in Hungary. In OTKA Kutatási Jelentésekl OTKA Research Reports; OTKA: San Francisco, CA, USA, 2008.

4. Eppich, B. Climatic Effects on the Phenology of Geophytes. Appl. Ecol. Environ. Res. 2009, 7, 253-266, doi:10.15666/aeer/0703_253266.

5. Hansen, J.; Sato, M.; Ruedy, R.; Lo, K.; Lea, D.W.; Medina-Elizade, M. Global temperature change. Proc. Natl. Acad. Sci. USA 2006, 103, 14288-14293, doi:10.1073/pnas.0606291103.

6. Hufnagel, L.; Sipkay, C. A Klímaváltozás Hatása Ökológiai Folyamatokra és Közösségekre; Budapesti Corvinus Egyetem: Budapest. Hungary, 2012; 531p.

7. Hunkár, M.; Vincze, E.; Szenyan, I.; Dunkel, Z. Application of phenological observations in agrometeorological models and climate change research. Idojaras 2012, 116, 195-209.

8. IPCC. Fourth Assessment Report of Intergovermental Panel onClimate Change. 2007. Available online: http://www.ipcc.ch (accessed on).

9. Jochner, S.C.; Sparks, T.H.; Estrella, N.; Menzel, A. The influence of altitude and urbanisation on trends and mean dates in phenology (1980-2009). Int. J. Biometeorol. 2011, 56, 387-394, doi:10.1007/s00484-011-0444-3.

10. Keresztes. B. Az Akác (Robinia pseudoacacia L); Akadémia Kiadó, Budapest, Hungary,1984. (in hungarian).

11. Krumbiegel, A. Growth forms of biennial and pluriennial vascular plants in central Europe. Nord. J. Bot. 1999, 19, 217-226, doi:10.1111/j.1756-1051.1999.tb00667.x.

12. Kunkel, K.E.; Easterling, D.R.; Hubbard, K.; Redmond, K. Temporal variations in frost-free season in the United States: 18952000. Geophys. Res. Lett. 2004, 31, 03201, doi:10.1029/2003gl018624.

13. Lehoczky, A. Testing Plant Phenophase as Proxy: Sensitivity Analysis of First Flowering Data from the 19th Century. Appl. Ecol. Environ. Res. 2016, 14, 213-233, doi:10.15666/aeer/1402_213233.

14. Li, L.; Cao, R.; Wei, K.; Wang, W.; Chen, L. Adapting climate change challenge: A new vulnerability assessment framework from the global perspective. J. Clean. Prod. 2019, 217, 216-224, doi:10.1016/j.jclepro.2019.01.162.

15. Lieth, H. Phenology and Seasonality Modeling. Ecological Studies 8; Springer: Berlin/Heidelberg, Germany, $1974 ;$ p. 444.

16. Massetti, L.; Petralli, M.; Orlandini, S. The effect of urban morphology on Tiliaxeuropaea flowering. Urban. For. Urban. Green. 2015, 14, 187-193, doi:10.1016/j.ufug.2014.10.005.

17. Millennium Ecosystem Assessment. Ecosystems and Human Well-Being: Synthesis; Washington: Island Press: Washington, DC, USA, 2005.

18. Menzel, A.; Fabian, P. Growing season extended in Europe. Nat. Cell Biol. 1999, 397, 659, doi:10.1038/17709.

19. Menzel, A. Trends in phenological phases in Europe between 1951 and 1996. Int. J. Biometeorol. 2000, 44, 76-81, doi:10.1007/s004840000054.

20. Molnár A.; Tökölyi, J.; Végvári, Z.; Sramkó, G.; Sulyok, J.; Barta, Z. Pollination mode predicts phenological response to climate change in terrestrial orchids: A case study from central Europe. J. Ecol. 2012, 100, 1141-1152, doi:10.1111/j.1365-2745.2012.02003.x.

21. Montreal Convention of Biological Diversity (2010) Conference of the Parties, Tenth Meeting, Nagoya, Japan, 18-29 October 2010, Agenda Item 4.7, Advance Unedited Text, 2 Nov 2010. Available online: http://www.cbd.int/ (accessed on 16 December 2010).

22. Neil, K.; Wu, J. Effects of urbanization on plant flowering phenology: A review. Urban. Ecosyst. 2006, 9, 243-257, doi:10.1007/s11252-006-9354-2.

23. Orlóci, L.; Kiszel, P.; Solymosiné László, I.; Papp, L. Delectus Seminum Sporarum Plantarumque Horti Botanici Univer-Sitatis Hungariae; Eotvos Lorand Tudomanyegyetem: Budapest, Hungary, 2019. 
24. Peñuelas, J. PHENOLOGY: Responses to a Warming World. Science 2001, 294, 793-795, doi:10.1126/science.1066860.

25. Primack, R.B. Patterns of Flowering Phenology in Communities, Populations, Individuals, and Single Flowers. In The Population Structure of Vegetation; Springer: Dordrecht, the Netherlands, 1985; Volume 3, pp. 571-593.

26. Primack, R.B.; Miller-Rushing, A.J. The role of botanical gardens in climate change research. New Phytol. 2009, 182, 303-313, doi:10.1111/j.1469-8137.2009.02800.x.

27. Rathcke, B.; Lacey, E.P. Phenological Patterns of Terrestrial Plants. Annu. Rev. Ecol. Syst. 1985, 16, 179-214, doi:10.1146/annurev.es.16.110185.001143.

28. Roetzer, T.; Wittenzeller, M.; Haeckel, H.; Nekovar, J. Phenology in central Europe-Differences and trends of spring phenophases in urban and rural areas. Int. J. Biometeorol. 2000, 44, 60-66, doi:10.1007/s004840000062.

29. Scheifinger, H.; Menzel, A.; Koch, E.; Peter, C. Trends of spring time frost events and phenological dates in Central Europe. Theor. Appl. Clim. 2003, 74, 41-51, doi:10.1007/s00704-002-0704-6.

30. Schieber, B.; Janik, R.; Snopková, Z. Phenology of four broad-leaved forest trees in a submountain beech forest. J. For. Sci. 2009, 55, 15-22, doi:10.17221/51/2008-jfs.

31. Schleip, C.; Sparks, T.; Estrella, N.; Menzel, A. Spatial variation in onset dates and trends in phenology across Europe. Clim. Res. 2009, 39, 249-260, doi:10.3354/cr00830.

32. Secretariat of the CBD. Global Strategy for Plant Conservation; Secretariat of the Convention on Biological Diversity: Rio de Janeiro, Brazil, 2002.

33. Szabó, B.; Vincze, E.; Czúcz, B. Flowering phenological changes in relation to climate change in Hungary. Int. J. Biometeorol. 2016, 60, 1347-1356, doi:10.1007/s00484-015-1128-1.

34. Szirmai, O.; Horel, J.; Neményi, A.; Pándi, I.; Gyuricza, C.; Czóbel, S. (2014): Overview of the collections of the first agrobotanical garden of Hungary. Hung. Agric. Res. 2014, 23, 19-25.

35. Templ, B.; Team, N.-P.; Templ, M.; Filzmoser, P.; Lehoczky, A.; Bakšienè, E.; Fleck, S.; Gregow, H.; Hodzic, S.; Kalvane, G.; et al. Phenological patterns of flowering across biogeographical regions of Europe. Int. J. Biometeorol. 2017, 61, 1347-1358, doi:10.1007/s00484-017-1312-6.

36. Thuiller, W.; Lavorel, S.; Araújo, M.B.; Sykes, M.T.; Prentice, I.C. Climate change threats to plant diversity in Europe. Proc. Natl. Acad. Sci. USA 2005, 102, 8245-8250, doi:10.1073/pnas.0409902102.

37. Varga, Z.; Varga-Haszonits, Z.; Gerencser, E.; Zs, L.; Milics, G. Bioclimatological analysis of the development of lilac (Robinia pseudoacacia L.). Acta Agron. Ovar. 2012, 54, 35-52 (in hungarian).

38. Walkovszky, A. Changes in phenology of the locust tree ( Robinia pseudoacacia L.) in Hungary. Int. J. Biometeorol. 1998, 41, 155160, doi:10.1007/s004840050069.

39. Zhang, X.; Friedl, M.A.; Schaaf, C.B.; Strahler, A.H. Climate controls on vegetation phenological patterns in northern mid- and high latitudes inferred from MODIS data. Glob. Chang. Biol. 2004, 10, 1133-1145, doi:10.1111/j.1529-8817.2003.00784.x.

40. Ziska, L.H.; Gebhard, D.E.; Frenz, D.A.; Faulkner, S.; Singer, B.D.; Straka, J.G. Cities as harbingers of climate change: Common ragweed, urbanization, and public health. J. Allergy Clin. Immunol. 2003, 111, 290-295, doi:10.1067/mai.2003.53.

41. The State of the Global Climate 2020. Available online: https://public.wmo.int/en/our-mandate/climate/wmo-statement-stateof-global-climate (accessed on 2 January 2021).

42. A Szélsőséges Időjárás Egyre Inkább a Globális Felmelegedés Számlájára Írható. Available online: https://www.met.hu/ismerettar/meteorologiai_hirek/index.php?id=1703 (accessed on 2 January 2021).

43. Climate Warming in Europe, Municipality by Municipality. Available online: https://www.europeandatajournalism.eu/eng/News/Data-news/Climate-warming-in-Europe-municipality-by-municipality (accessed on 30 December 2020).

44. UERRA Regional Reanalysis for Europe on Single Levels from 1961 to 2019. Available online: https://cds.climate.copernicus.eu/cdsapp\#!/dataset/reanalysis-uerra-europe-single-levels?tab=overview (accessed on 30 December 2020). 